\title{
Early fragmentation of polyester urethane sheet neither causes persistent oxidative stress nor alters the outcome of normal tissue healing in rat skin
}

\author{
SANDRO M. SGROTT ${ }^{1,2}$, RODRIGO D. NEVES ${ }^{2}$, ARMANDO J. D'ACAMPORA ${ }^{2}$, GERALDO J.S. BERNARDES ${ }^{2}$, \\ LUIZ BELMONTE ${ }^{1,3}$, THIAGO C. MARTINS ${ }^{4}$, FRANCIANE BOBINSKI ${ }^{1}$, EDUARDO CARGNIN-FERREIRA ${ }^{5}$, \\ ANDREZA HOEPERS ${ }^{1}$, CLARISSA M. COMIM ${ }^{1,3}$, DANIEL F. MARTINS ${ }^{1,3}$ and ANNA P. PIOVEZAN ${ }^{1,3}$
}

\author{
${ }^{1}$ Programa de Pós-Graduação em Ciências da Saúde, Universidade do Sul de Santa Catarina/ \\ UNISUL, Avenida Pedra Branca, 25, 88137-270 Palhoça, SC, Brazil \\ ${ }^{2}$ Laboratório de Técnicas Cirúrgica e Experimental/TOCE, Universidade do Sul de Santa \\ Catarina/UNISUL, Avenida Pedra Branca, 25, 88137-270 Palhoça, SC, Brazil \\ ${ }^{3}$ Laboratório de Neurociência Experimental/LaNex, Universidade do Sul de Santa Catarina/ \\ UNISUL, Avenida Pedra Branca, 25, 88137-270 Palhoça, SC, Brazil \\ ${ }^{4}$ Programa de Pós-Graduação em Neurociências, Universidade Federal de Santa Catarina/ \\ UFSC, Centro de Ciências Biológicas, 88040-900 Florianópolis, SC, Brazil \\ ${ }^{5}$ Laboratório de Marcadores Histológicos, Instituto Federal de Santa Catarina/IFSC, Rua Maria \\ Aparecida Barbosa, 153, Bairro Campo D’Una, 88495-000 Garopaba, SC, Brazil
}

Manuscript received on August 29, 2017; accepted for publication October 31, 2017

\begin{abstract}
Silicone breast implant is associated with complications inherent to the surgical procedure. Prosthesis coating with polyurethane, however, commonly reduces the incidence of such complications. In this paper, the authors evaluated the inflammatory histomorphometric profile and oxidative damage associated to the implant of polyester urethane sheets. Forty-eight Wistar rats were divided into Sham or polyester urethane groups ( $\mathrm{n}=8$ /group) and underwent a polyester urethane implant in the dorsal skinfold. Tissue samples were collected on days seven, 30, and 90 after surgery and subjected to histomorphometric analysis and biochemical tests. Results were analyzed by one-way ANOVA $(\mathrm{p} \leq 0.05)$. Peri-implant tissue samples exhibited characteristic inflammatory response associated with the biomaterial, with increased vascularization on day seven and augmented levels of IL1-b and TNF-a after 30 days. Peri-implant fibrocystic population was small on day seven, but increased considerably after 90 days. A rise in the carbonyl group levels of skin samples in the polyester urethane group was observed on day seven. Findings suggest that polyester urethane sheets undergo biodegradation at an early stage after implantation, followed by increased vascularity and microencapsulation of biomaterial fragments, without persistent oxidative damage. Fiber arrangement inside the collagen matrix results in a fibrotic scar because of polyester urethane degradation.
\end{abstract}

Key words: Polyurethane, inflammation, cytokines, oxidative stress, Wistar rats.

Correspondence to: Anna Paula Piovezan

E-mail: anna.piovezan@unisul.br

* Contribution to the centenary of the Brazilian Academy of

Sciences. 


\section{INTRODUCTION}

Polyurethanes (PU) biomaterial have been used in biomedical areas for several decades. Since its development in 1970, PU-coated silicone gel implants have been investigated in order to understand biological responses to implant materials and avoid infection and local pain in early stages (Scarpa et al. 2015), as well as breast capsular contracture (De La Peña-Salcedo et al. 2012, Berry and Davies 2010) in later stages, which was the main undesirable complication responsible for its withdrawal from the US market in the late 1980s. From then onwards, considerable changes have been made to the PU-coated implants, resulting in a sole product available for Latin America (Silimed $^{\mathrm{TM}}$ ) and Europe (PolytechSilimed ${ }^{\mathrm{TM}}$ ). However, inflammatory reaction to degradation of polyester-urethane component of PU-coating alone is not fully elucidated yet. Experimental works in animals have focused on the influence of the entire prosthesis on biomechanical stress, molecular morphology and in vivo interactions with cells of the immune system (Labow et al. 2001, 1998, Sutherland et al. 1993), as well as in inflammatory response to biomaterial micro-fragments (Vieira et al. 2010, Mendes et al. 2008).

Considering the above mentioned, it seems important to identify the profile of a particular inflammatory response to PU alone, in order to better understand the phenomena caused by each of the prosthesis components. The present study investigated acute and chronic inflammatory responses to PU sheets implanted subcutaneously in rats.

\section{MATERIALS AND METHODS}

\section{ANIMALS}

Forty-eight female rats (Rattus norvegicus albinus), 90 days old, weighing $300-350 \mathrm{~g}$, from the Federal University of Santa Catarina were used for the experiment conducted in the LaNEx laboratory at UNISUL. They were maintained in a 12 hour light:dark cycle, under controlled temperature (22 ${ }^{\circ} \mathrm{C} \pm 1{ }^{\circ} \mathrm{C}$ ) and humidity (60 - 80\%), receiving food and water ad libitum.

\section{GROUPS}

The animals were divided into two experimental groups. The animals of the PU group underwent surgery to implant polyester urethane sheets $2 \mathrm{~cm}$ wide $X 2 \mathrm{~cm}$ long X $2 \mathrm{~mm}$ thick in the dorsal skinfold of rats. The rats of the Sham group underwent the same procedures, except that no biomaterial was implanted.

\section{BIOMATERIAL CHARACTERISTICS}

PU sterilized sheets were supplied by Silimed $\AA$ (Rio de Janeiro, Brazil). Some physical and chemical characteristics of the material used are: PU from medical grade based on toluene diisocyanate (TDI) and forming polymers containing the urethane linkage (Guelcher 2008, Santerre et al. 2005).

Since the 1990s, it has been known that polyurethanes undergo oxygen-dependent degradation by phagocytes (Sutherland et al. 1993). Isocyanates, components of polyurethanes, can also react with intracellular glutathione, either directly or via catalysis, through the glutathione transferase (GST) system (Er et al. 2007). This reaction is important because GSTs are enzymes involved in protecting the body against reactive oxygen species (ROS), which is an important component to activate the initial inflammatory response to biomaterials; because of this, taking into account the protective role for the redox cycle of glutathione and enzymes that compose its metabolism in avoiding cellular impairment from the attack of these radicals, analysis for the determination of glutathione levels were not performed in tissue sample in the present study since our main goal was to investigate potential damages associated to subcutaneous PU implant. In addition, the oxidation and enzymatic hydrolysis stages have in common the fact that their active agents come 
from the same biological sources, the activated white blood cells, such as monocyte-derived cells, and foreign-body giant cells (FBGCs) (Labow et al. 2001, Sutherland et al. 1993).

\section{ANIMAL SURGERY FOR PU IMPLANT}

The experimental animals were anesthetized by intramuscular injection of $5 \%$ dextro-ketamine hydrochloride $(40 \mathrm{mg} / \mathrm{kg})$ and $2 \%$ xylazine $(10$ $\mathrm{mg} / \mathrm{kg}$ ) to obtain a surgical anesthesia level. Then, they were placed in the prone position on a wooden board measuring $30 \mathrm{~cm} \mathrm{X} 35 \mathrm{~cm}$. Trichotomy was performed on the dorsal region, followed by antisepsis of the surgical field with $10 \%$ aqueous polyvidone iodine. The animal skin incision, blunt dissection, and implant were then reproduced as previously described (Vieira et al. 2010). All protocols were following the 'Guide for the Care and Use of Laboratory Animals' and were approved by the UNISUL Ethics Committee on Animal Experimentation (protocol no. 13.030.4.03.IV).

\section{SAMPLE COLLECTION}

Different animals from each group were anesthetized again after seven, 30, or 90 days, and anatomical specimens were removed en bloc with a $1 \mathrm{~cm}$ peri-implant margin. A cutaneous fragment was excised exposing the dorsal muscular fascia for histological studies (in 10\% formalin), as well as for inflammatory cytokine and oxidative stress analysis $\left(-80^{\circ} \mathrm{C}\right)$. Then, the rats were subjected to euthanasia.

\section{HISTOLOGICAL ANALYSIS}

Samples were fixed, embedded, sectioned and prepared in histological slides for staining with hematoxylin-eosin, Giemsa, May-Grünwald or Vanderbilt techniques. Histological changes in each sample were described qualitatively in accordance with the method described previously (Vieira et al. 2010) from panoramic sections (10 X) or immersion
(1,000 X). An optical microscope (Leica ${ }^{\circledR}$ DM-500) was used to capture the images, and the delimitation of the cell count fields was obtained with the aid of the ToupView 64 V 3.7 software (ToupTec ${ }^{\circledR}$ 200314), coupled to an Opticam ${ }^{\circledR} A 050$ system. Cell and blood vessel count (number $/ \mu \mathrm{m}^{2}$ ) was performed in two different fields of each slide within an area of $50 \mu \mathrm{m}^{2}$ X $40 \mu \mathrm{m}^{2}$, whereas the thickness of collagen fibers was obtained by the average of four measurements per field. Both evaluations were performed at $400 \mathrm{X}$ magnification.

\section{MEASUREMENT OF PRO-INFLAMMATORY CYTOKINE LEVELS}

Following the previously described (Gretzer et al. 2003), samples were homogenized with an UltraTurrax homogenizer (IKA T18 basic, IKA ${ }^{\circledR}$ ) in a phosphate-buffered saline (PBS) solution containing Tween 20 (0.05\%), $0.1 \mathrm{mM}$ phenylmethylsulphonyl fluoride (PMSF), $10 \mathrm{mM}$ ethylenediaminetetraacetic acid (EDTA), $2 \mathrm{ng} / \mathrm{ml}$ Aprotinin, and $0.1 \mathrm{mM}$ benzemethonium chloride. Homogenates were transferred to $1.5 \mathrm{~mL}$ Eppendorf tubes, centrifuged at $3000 \times \mathrm{g}$ for $10 \mathrm{~min}$ at $4{ }^{\circ} \mathrm{C}$ and total protein content was measured in the supernatant. Sample aliquots of $100 \mu \mathrm{l}$ were used to measure the tumor necrosis factor-alpha (TNF- $\alpha$ ) (DY510) and interleukin-1 beta (IL-1 $\beta$ ) (DY501) levels using rat cytokine ELISA kits from R\&D Systems, according to the manufacturer's instructions. The sensitivity estimates ranged from 62.5 to $4000 \mathrm{pg} / \mathrm{mL}$. Cytokine levels were estimated by interpolation from a standard curve by colorimetric measurements at 450 $\mathrm{nm}$ (correction wavelength $540 \mathrm{~nm}$ ) in an ELISA plate reader (Berthold Technologies - Apollo 8 - LB 912, Bad Wildbad, KG). All results were expressed as $\mathrm{pg} / \mathrm{mg}$ protein.

\section{ASSESSMENT OF POSSIBLE IMPLANT-INDUCED OXIDATIVE STRESS}

The level of thiobarbituric acid reactive substances (TBARS) was measured during a 
heated acid reaction, resulting in the formation of malondialdehyde (MDA). Samples were homogenized in PBS mixed with $1.0 \mathrm{~mL}$ of $10 \%$ trichloroacetic acid and $1.0 \mathrm{~mL}$ of thiobarbituric acid, and boiled for $15 \mathrm{~min}$. TBARS amount was determined by absorbance at $535 \mathrm{~nm}$ and recorded as MDA equivalent content ( $\mathrm{nmol} / \mathrm{mg}$ protein). Analysis of oxidative damage to protein carbonyl groups was determined by the reaction with dinitrophenylhydrazine (DNPH). Briefly, samples were precipitated with $20 \%$ trichloroacetic acid and redissolved in DNPH. Readings of the amount of protein carbonyl groups were carried out in a spectrophotometer, measured by absorbance at $370 \mathrm{~nm}$ and were expressed as nmol/mg protein as described previously (Gretzer et al. 2003).

\section{STATISTICAL ANALYSIS}

All results were expressed as mean \pm SEM. After confirmation of normality by the KolmogorovSmirnov test, the data variables were analyzed using One-way ANOVA, followed by Tukey's test. The significance level for all tests was set at $\mathrm{p}<$ 0.05 .

\section{RESULTS}

Histologically, the evolution of the inflammatory response and tissue regeneration followed normality patterns. In the PU group, various degrees of fragmentation and dispersion, neovascularization and microencapsulation (biodegradation) of the biomaterial sheets were observed, mainly within 30 - 90 days after surgery (Figure 1).

Histomorphometry analysis revealed that the biomaterial degradation profile associated with an inflammatory response has a cell characteristic profile associated with neovascularization, without compromising the structure, and deposition of collagen fibers (Figure 2). Cell density encircling the biomaterial fragments (microencapsulation) was accentuated and constant at different observation periods. Photomicrography showed that fragmentation of the biomaterial occurred even at an early stage (seven days). Reactions associated with PU degradation exhibited a cellular infiltrate, consisting mainly of macrophages and FBGC, as shown in Figure 2d-g. Moreover, there was neither polymorphonuclear (PMN) accumulation and signs of rejection nor infection at the surgical site throughout the observation period.

Quantitative differences in cell types were observed between the two groups during the chronological development of the inflammatory response to biomaterial implant (Figure 3). Mononuclear cell infiltration at day seven was higher than that observed at other time intervals in the Sham group $\left(26.5 \pm 1.6\right.$ cells $\left./ \mu \mathrm{m}^{2}\right)$, as well as that compared with the same period in the PU group $\left(14.1 \pm 0.5\right.$ cells $\left./ \mu \mathrm{m}^{2}\right)$. However, the innate immune response against the biomaterial implant leads to a reversal of this profile, given that at day 30 after surgery, the PU group had a higher number of these cells than those observed at other time intervals (day 30: $32.4 \pm 1.9$ cells $/ \mu^{2}$; day $90: 31.7$ \pm 1.5 cells $\left./ \mu \mathrm{m}^{2}\right)$. Unlike this first cell type, FBGCtype cells in the implanted area were higher for the PU group at day seven $\left(1.9 \pm 0.3\right.$ cells $\left./ \mu \mathrm{m}^{2}\right)$ as compared to the Sham group, remaining elevated at day $30\left(1.5 \pm 0.3\right.$ cells $\left./ \mu \mathrm{m}^{2}\right)$. A special feature in relation to the development of peri-implant tissue after microencapsulation of biomaterial was revealed by the kinetics of fibroblast-type cell appearance. Whereas no difference was found between the two groups at day seven after surgery (Sham: $20.4 \pm 1.7$ cells $/ \mu m^{2}$; PU: $18.1 \pm 1.5$ cells/ $\mu \mathrm{m}^{2}$ ), a smaller number of these cells was observed in the PU group at day $30\left(22.9 \pm 1.1 \mathrm{cells} / \mu \mathrm{m}^{2}\right.$ and $16.5 \pm 2.0$ cells $/ \mu \mathrm{m}^{2}$, respectively). This effect was reversed at day 90 by a rise in the number of cells in the PU group $\left(20.0 \pm 1.6\right.$ cells $/ \mu \mathrm{m}^{2}$ and $11.6 \pm$ 0.9 cells $/ \mu \mathrm{m}^{2}$, respectively). It also complements the results of deposition of the collagen matrix, which showed greater thickness $(1.21 \pm 0.07 \mu \mathrm{m})$ 

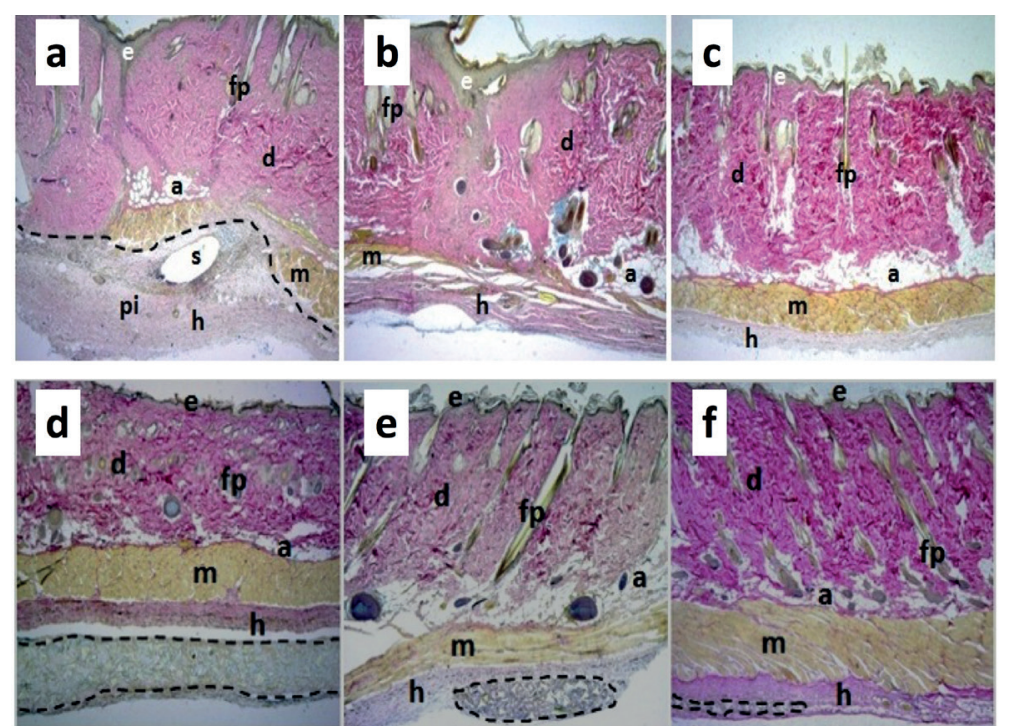

Figure 1 - Panoramic images representative of histological sections of the dorsal skin of rats at days 7, 30, or 90 after surgery in animals from the Sham (ac) or PU (d-f) groups, stained by Vanderbilt coloring at 40X magnification. In both groups, there is intense cellularity of mononuclear and FBGC cells in the hypodermis (h) surrounding the suture (s) at peri-implant tissue (pi), indicating the inflammatory process (below the dashed line), whereas epidermis (e) and dermis (d) are intact with typical layers of adipocytes (a) and skeletal muscle (m), and the presence of hair follicles (fp) in the Sham group. (d) During the acute phase of the inflammatory response in the PU group, PU is intact and thick, reflecting onset of activity for FBGC surrounding it (dotted line). (e) At day 30 , the implanted material is fragmented, probably reflecting effective macrophage depletion by FBGC and indicating intermediate healing process and tissue regeneration. (f) Chronic phase of the inflammatory response (day 90), with reduced cellularity (mononuclear and FBGC) involving polyurethane (dashed line) in the hypodermis, which is quite reduced and fragmented, whereas collagen fibers and hair follicles have structures that do not differ between the Sham and PU groups, indicating the end of the healing process with complete tissue regeneration.

at day 90 in the PU group as compared to the other observation periods in the same group and in the same period of time in the Sham group $(0.95 \pm 0.04$ $\mu \mathrm{m})$. Furthermore, vascularization was similar to the antigenic response to the biomaterial, particularly increased within seven days after implantation in the PU group $\left(5.4 \pm 1.0\right.$ vessels $\left./ \mu \mathrm{m}^{2}\right)$ as compared to the Sham $\left(2.0 \pm 0.3\right.$ vessels $\left./ \mu \mathrm{m}^{2}\right)$ group, with a gradual decline in the experimental group as the PU sheet undergoes intensive phagocytosis (day 90: $1.6 \pm 0.4$ vessels $/ \mu \mathrm{m}^{2}$ ).

Regarding inflammatory cytokine levels, differences were also observed between the two groups throughout the observation period (Figure 4). Mean values for TNF-a levels were similar between the two groups at day seven (Sham: $164.2 \pm 20.3 \mathrm{pg} / \mathrm{mg}$ protein; PU: $179.1 \pm 32.9$ $\mathrm{pg} / \mathrm{mg}$ protein) and day 90 (Sham: $4.8 \pm 0.6 \mathrm{pg} /$ $\mathrm{mg}$ protein; PU: $5.5 \pm 0.8 \mathrm{pg} / \mathrm{mg}$ protein) after the procedure, but they were increased at day 30 in the PU group $(243.4 \pm 30.8 \mathrm{pg} / \mathrm{mg}$ protein $)$ as compared to the Sham group $(114.0 \pm 28.8 \mathrm{pg} /$ $\mathrm{mg}$ protein). Similarly, IL-1b levels were different only within the 30 -day post-operative period, being higher in the PU group $(82.5 \pm 10.6 \mathrm{pg} / \mathrm{mg}$ protein $)$ 


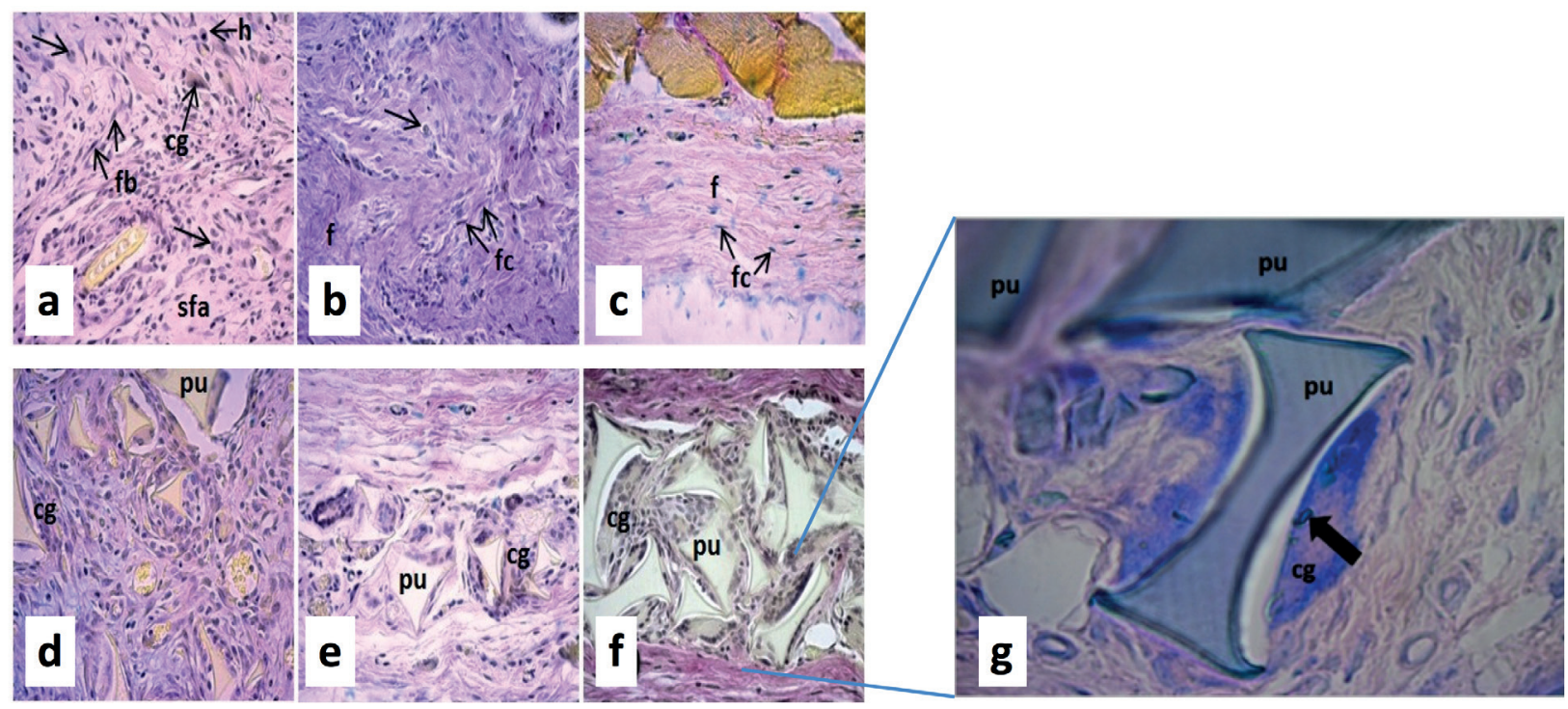

Figure 2 - Panoramic images representative of histological sections of the dorsal skin of rats at 7, 30, or 90 days after surgery in animals from the Sham (a-c) or PU (d-f) groups, stained by Vanderbilt coloring at 400X magnification. In the Sham group, (a) during the acute phase of inflammatory response, intense cellularity is observed in the hypodermis, with high presence of histiocytes (h), FBGC (cg), mononuclear (arrows) and fibrocytes (fb) responsible for the production of ground substance (sfa); all these aspects are indicating the initial phase of the healing process. (b) At day 30, the inflammatory process is still active in this group, but a tendency toward cellular density reduction can be observed, with higher presence of fibrocytes (fc) and collagen fibers (f), which reflects a fine evolution of tissue regeneration. (c and f) Chronic phase of the inflammatory response (day 90), showing a remarkable presence of collagen fibers in both groups, at the same extent and similar thickness, reflecting desirable tissue regeneration and complete healing. (d, e) Contrasting with the Sham group, PU-implanted animals showed a higher number of FBGC surrounding this material, which is suggestive of intense innate immune response to it. (g) FBGC nature of these cells and their role in the degradation of the material seems to be acceptable, since in photomicrography of representative histological section from animal samples, at 90-day after the implant, stained by Giemsa coloring, at 1000X magnification, multinuclear structure and polyurethane fragments (pu) can be observed inside the cytoplasm (arrow).

as compared to the Sham group $(30.8 \pm 15.2 \mathrm{pg} / \mathrm{mg}$ protein).

For the analysis of the potential oxidative damage associated with the inflammatory response and tissue regeneration from the implant PU sheet on the dorsal skinfold of rats (Table I), there were statistical differences only in the protein oxidation, with an increase in the PU group at day seven (4.06 $\pm 0.45 \mathrm{nmol} / \mathrm{mg}$ protein) as compared to the Sham group $(1.7 \pm 0.1 \mathrm{nmol} / \mathrm{mg}$ protein $)$.

\section{DISCUSSION}

Intrinsic characteristics of the implanted biomaterial may influence the inflammation outcome and tissue regeneration (Ekdhal et al. 2011, Franz et al. 2011). Histological findings from this study corroborate that the inflammatory response to PU sheet and tissue regeneration depend on processes that occur continuously in a state of interaction between the different endogenous and exogenous body components. Organic reactions against the implant of PU-coated breast prosthesis is characteristic both in experimental models (Bergmann et al. 2014, Wagenführ-Júnior et al. 2012, Vieira et al. 2010, Mendes et al. 2008), and in clinical routine (Duxbury and Harvey 2016, Frame et al. 2015, Dancey et al. 2012, De La Peña-Salcedo et al. 2012, Mossaad and Frame 2012). However, the tissue regeneration kinetics and inflammatory response to biomaterial-coated implant currently used, in its isolated form, is not properly described, although a range of reactions in the immune system, blood clot 

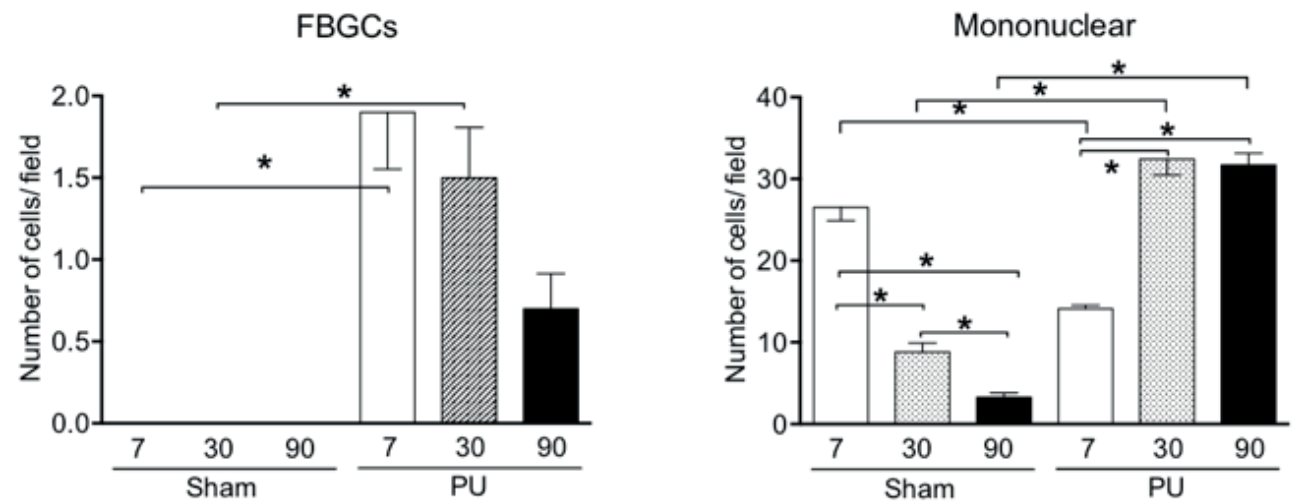

Fibroblasts
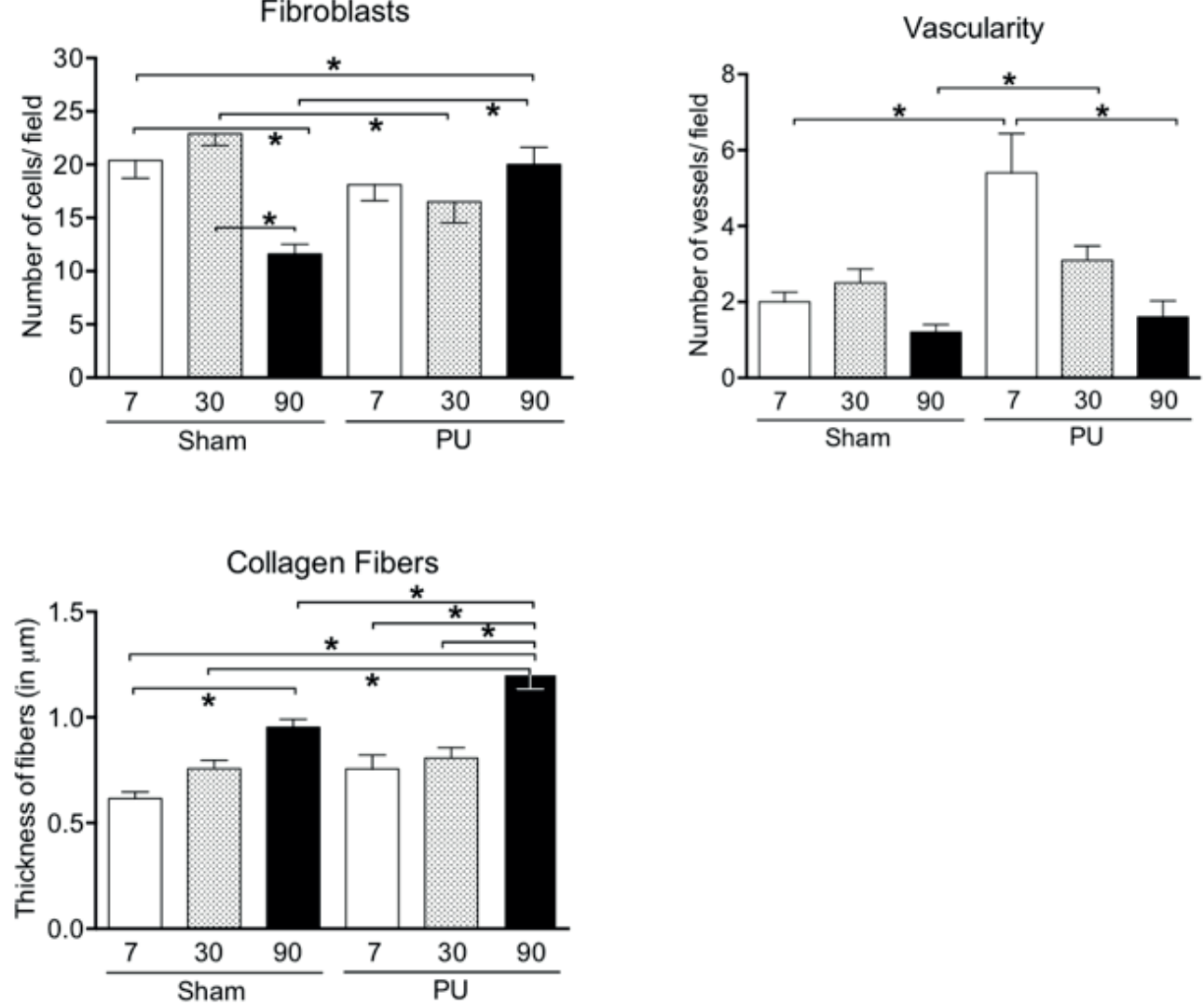

Figure 3 - Influence of PU on histologic parameters on dorsal skin of rats at different time intervals (7, 30 or 90 days) after the implant. Data are presented as mean \pm S.E.M. ( $n=8$ animals per group). One-way ANOVA followed by Tukey's test; $\left(^{*}\right) \mathrm{p} \leq 0.05$ in relation to control group (sham).

and extracellular matrix have been studied (Franz et al. 2011, Strecker-McGraw et al. 2007). The role of immune macrophages starts in "frustrated phagocytosis" situations, when they coalesce and form FBGC (immune theory), which is responsible for limiting the functionality of implants and devices (Franz et al. 2011, Jones 2008). In addition, mononuclear cells may secrete important molecules for antigen processing and presentation, as well as cytokines and chemo-attractive substances to other white blood cells (Ortega-Gómez et al. 2013, Franz et al. 2011, Serhan et al. 2011).

In the present study, seven days after PU implant, this biomaterial caused a mild inflammatory 
TABLE I

Influence on different biochemical parameters of oxidative stress induced by PU implant in the dorsal skin of rats.

\begin{tabular}{ccc}
\hline \multirow{2}{*}{ Period after implant/Group } & \multicolumn{2}{c}{ Parameter } \\
\cline { 2 - 3 } 7 days & MDA (nmol/mg of protein) & Carbonil (nmol/mg of protein) \\
sham & $0.002504 \pm 0.000040$ & $1.66 \pm 0.12$ \\
PU & $0.002597 \pm 0.000086$ & $4.06 \pm 0.45^{*}$ \\
30 days & & $2.72 \pm 0.18$ \\
sham & $0.002473 \pm 0.000085$ & $3.27 \pm 0.43$ \\
PU & $0.002465 \pm 0.000097$ & $4.54 \pm 0.20$ \\
90 days & & $4.75 \pm 0.23$ \\
sham & $0.002355 \pm 0.000136$ & $0.002410 \pm 0.000093$ \\
PU
\end{tabular}

Data presented as mean \pm S.E.M. (standard error of the mean, $n=8$ samples). One-way ANOVA followed by Turkey test $(p \leq 0.05)$. (*) Significant difference in relation to sham group.
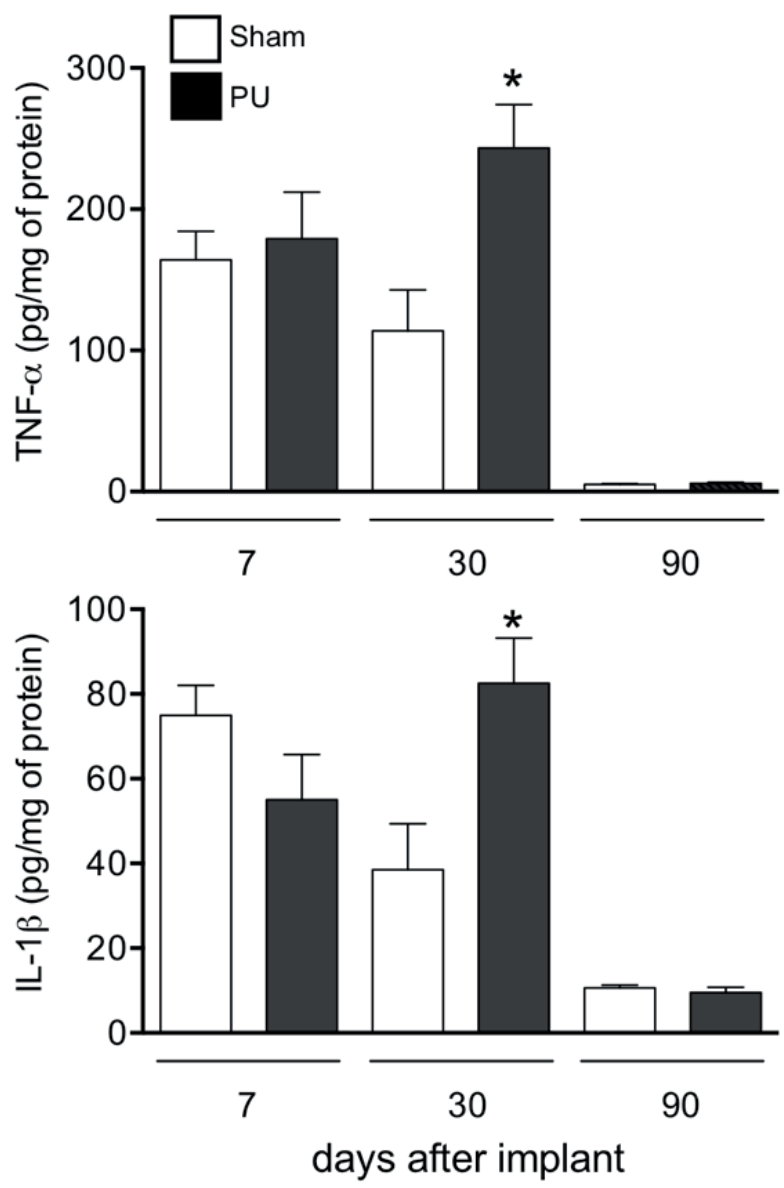

Figure 4 - Influence of PU on cytokine levels of the dorsal skin of rats at different time intervals after the implant. Data are presented as mean \pm S.E.M. ( $n=8$ animals per group) in relation to the Sham group. One-way ANOVA followed by Tukey's test; (*) p $\leq 0.05$. reaction, with the presence of mononuclear cells, sheet fragmentation, microencapsulation of biomaterial by FGBC, recruitment of fibrocytes, and intense vascularization. Although using a different species and without evaluating tissue determination of pro-inflammatory cytokine and oxidative stress, as analyzed in our study, Devor et al. (1993) found a similar cell profile after implantation of PU discs (Poly-ester-urethane grade 5-6) in axillary and inguinal mammary pads of female mice. In Devor's study (Devor et al. 1993), however, PU disks were soaked overnight in $70 \%$ ethanol, which, according to some authors (Shutte et al. 2009), could promote a structure alteration of the material that would favor biodegradation.

TNF- $\alpha$ is one of the main mediators of the early inflammatory response, and it is important for the development, maintenance and progress of the inflammation (Ekdhal et al. 2011, Franz et al. 2011). IL-1 $\beta$, in turn, has similar functions to those of TNF- $\alpha$ in mediating pro-inflammatory host defense and its synthesis, and release can also be associated with TNF- $\alpha$ exposure (OrtegaGómez et al. 2013, Serhan et al. 2011, Jones 2008). Mononuclear phagocytes are the main source of these cytokines (Franz et al. 2011, StreckerMcGraw et al. 2007); in the present study, the lack 
of difference in the levels of TNF- $\alpha$ and IL-1-b in samples of peri-implant tissue between the two groups during the acute phase of inflammation (day seven) is in agreement with findings from other authors after implantation of diverse biomaterials. In this regard, Shutte et al. (2009) implanted highdensity polyethylene, polyurethane/pellethane or organo-tin stabilized polyvinyl chloride in the dorsal region of rats, within stainless steel meshes, and found that cytokine (including TNF-a and IL-1b) concentrations decreased from days one and two to day eight post-implant. Besides, early interactions $(24 \mathrm{~h})$ between degradable poly(urethane urea), cell culture treated polystyrene surfaces, and commercially pure titanium and mononuclear unstimulated or LPS-stimulated cells, as well as the secretory response of this type of cells after exposure to biomaterials were evaluated by Gretzer et al. (2003). At this point in time, the authors found an elevation on TNF-a in stimulated samples; however, material-related differences in unstimulated cells were observed. Together, these results could strengthen the idea that differences in implanted biomaterials can drive inflammatory responses with distinctive mediators and kinetic profile.

Inflammatory processes can develop into one of the three possible outcomes, encompassing full resolution, healing with the growth of connective tissue in the exudate area (organization), or progression of tissue response to chronic inflammation (Headland and Norling 2015, OrtegaGómez et al. 2013, Delavary et al. 2011, Franz et al. 2011, Serhan et al. 2011, Thevenot et al. 2011). So, inflammatory response is closely related to tissue regeneration, which begins in the early stages of the inflammatory process. In this study, there was intense cellularity in the peri-implant tissue involving fragmented biomaterial sheet, at day 30 of the observation period, suggestive of effective macrophagy (Franz et al. 2011, Mendes et al. 2008, Santerre et al. 2005, Sutherland et al. 1993). During this period, epidermis and dermis were undamaged in both groups, presenting typical layers of the species. In the dermis, similar results were obtained regarding to neovascularization, collagen fibers, hair follicles, intradermal adipocytes and skeletal muscle, even though there was a greater number of fibrocytes in the Sham group as compared to the PU group, suggesting intermediate healing stage (Devor et al. 1993). The findings from vascularization and collagen thickness from this period of observation onwards can be considered as protective factors against the appearance of capsular contracture, according to the formation of what other authors defined as "young" peri-implant capsule. This idea is supported by findings from animal studies (Vieira et al. 2010) or human patients' data (Duxbury and Harvey 2016, Dancey et al. 2012), indicating that the degradation of PU biomaterial layer would prevent the adhesion of fibrocytes and subsequent differentiation into contractile cells that would be responsible for the contraction of collagen fibers, leading to contracture. Similar histologic findings were found in other experimental studies with mini-implants coated with the same biomaterial as that evaluated in this study (Bergmann et al. 2014, Wagenführ-Júnior et al. 2012, Vieira et al. 2010, Mendes et al. 2008) or PU sheets (Devor et al. 1993). With regard to cytokines, the increase in TNF- $\alpha$ and IL-1 $\beta$ levels in the PU group as compared to the Sham group is consistent with the cellular infiltrate recorded during this observation period of the inflammatory response, as well as the expected inflammatory response to the implanted biomaterial (Ekdhal et al. 2011, Franz et al. 2011). In the exudate from the tissue cages containing different biomaterials (Berry and Davies 2010), the content of all cytokines, normalized in relation to the empty cages, has shown an increased upregulation of TNF- $\alpha$ and IL-1-b, in a similar period (28 days), possibly associated with continuing immune response to the implanted material, whereas for the 
empty cages this response would have undergone a resolution process.

At the later period (90 days) of the inflammatory response against PU, the cellular profile was maintained in hypodermis, associated with increased presence of fibrocytes surrounding the biomaterial fragments (microcapsules), indicating an acute inflammation transition to a chronic process with capsular maturation (Franz et al. 2011, Thevenot et al. 2011). Once more, in this period, the PU sheet was quite small and fragmented, indicating a very effective macrophage depletion by the FBGCs (Santerre et al. 2005, Labow et al. 2001). However, there was a reduction of vascularization and the presence of polymerized collagen fibers surrounding the biomaterial, with higher thickness than that found in the other observation periods, which can be considered characteristic of a final healing process (Delavary et al. 2011, Franz et al. 2011, Shutte et al. 2009). These results are in agreement with the histological findings at 60 (Bergmann et al. 2014) and 90 (Mossaad and Frame 2012, Vieira et al. 2010) days, suggesting that the extent to which PU undergoes phagocytosis, there is a reduction in the immune stimulus and a transition to a chronic inflammatory process. This could also influence the levels of proinflammatory TNF- $\alpha$ and IL- $1 \beta$ cytokines, which were reduced during this period (Franz et al. 2011).

Finally, we evaluated oxidative stress parameters of the dorsal rat skin submitted to PU sheet implant, given that the innate inflammatory response associated with biomaterials causes local biological responses associated with this phenomenon (Headland and Norling 2015, Ortega-Gómez et al. 2013, Delavary et al. 2011, Franz et al. 2011, Serhan et al. 2011, Thevenot et al. 2011), especially when PU-based composites are used. (Santerre et al. 2005, Labow et al. 2001, 1998, Sutherland et al. 1993). Lipid constituents of various structures in the body can be oxidized, halogenated, or undergo nitration by a wide variety of reactive species (RS). When RS production exceeds antioxidant defense systems, the excessive SR can oxidize membrane lipids, denature proteins, and attack nucleic acids, which form the molecular basis of various inflammatory-associated diseases (Er et al. 2007). In this regard, samples from PU group revealed oxidative damage to proteins with carbonyl groups only at day seven after implant of the observation period, without causing damage to lipids (peroxidation). This can be explained in part by the possibility that a mild inflammatory response against the biomaterial may be occurring, as well as by the fact that the tegumental tissue of the rat has a higher proportion of protein in relation to the amount of lipids. The relatively constant levels of TBARS along the period of study is in agreement with the literature when evaluating healthy adult animals (Tahara et al. 2001). The cellular profile observed at this point confirms the data involving the function of the different mononuclear and FBGC (Franz et al. 2011, Schäfer and Werne 2008) for the production of RS forming carbonyl compounds (Höhn et al. 2014, Zhai et al. 2012, Rees et al. 2008) and the histological pattern also reinforces the central role of these cells along the time course degradation of the evaluated biomaterial with different methodologies (Vieira et al. 2010, Santerre et al. 2005, Sutherland et al. 1993) or non-homologous variations of PU (Shutte et al. 2009, Labow et al. 2001, 1998). Besides, recruitment of inflammatory cells by RS at this point in time could contribute for augmented levels of cytokines at day 30 after implant, as observed in the present study.

All together, these results reinforce the accumulated data, indicating that biodegradation of polyurethanes involves oxygen-dependent reactions promoted by phagocytes, as well as by the action of enzymes, such as intracellular glutathione, and generation of reactive oxygen species (ROS), which constitute an important component of initial inflammatory response to biomaterials. The results 
also reinforce previous descriptions regarding the fact that oxidation and enzymatic hydrolysis steps use intermediary cells derived from activated white blood cells, such as monocyte-derived macrophages and FBGCs. Despite this effect, PU biodegradation is initiated by the action of mechanical forces acting upon the biomaterial, as well as by the activity of host-defense cells with the production of ROS on the implant (Frame et al. 2015).

In conclusion, this study showed that the polyurethane sheet undergoes biodegradation in an early period, related to an innate immune response and a persistent mononuclear cell phagocyte profile. The levels of pro-inflammatory cytokines (TNF- $\alpha$ and IL-1 $\beta$ ) in the peri-implant tissue did not show any difference between the two studied groups within the seven-day observation period, which suggests that surgery and surgical techniques were responsible for the endogenous response to trauma and tissue regeneration. At day 30, high cytokine levels were observed in the PU group, indicating an association between the organic response to $\mathrm{PU}$ and the cells present in the tissue. Low levels of cytokines observed at 90-day after implant suggest a resolution of inflammation to biomaterial, a view strengthened by changes in the collagen matrix, reduced cellular density, and remission of vascularization. Oxidative damage associated with the inflammatory response to PU was found only within the seven-day post-implant period, only for proteins with carbonyl groups. This event seems to be related to rat tissue characteristics, rather than to a specific reaction to this biomaterial, which can be of interest for new clinical applications (Guelcher 2008).

These are innovative aspects reveled on in this study since other studies have not investigated inflammatory reaction to degradation of polyesterurethane component of PU-coating alone. Results of the present study research contribute to the scientific community in order to better understand the phenomena caused by each of the prosthesis components, isolated. The fact that the early fragmentation of the polyester urethane layer does not cause persistent oxidative stress nor alter the result of normal tissue healing in rat skin could suggest that it may be employed in prosthesis for application in other organs/tissues in different clinical conditions.

\section{REFERENCES}

BERGMANN PA, TAMOURIDIS G, LOHMEYER JA, MAUSS KL, BECKER B, KNOBLOCH J, MAILÄNDER P AND SIEMERS F. 2014. The effect of a bacterial contamination on the formation of capsular contracture with polyurethane breast implants in comparison with textured silicone implants: An animal study. J Plast Reconstr Aesthet Surg 67: 1364-1370.

BERRY MG AND DAVIES DM. 2010. Breast augmentation: Part I - a review of the silicone prosthesis. J Plast Reconstr Aesthet Surg 63: 1761-1768.

DANCEY A, NASSIMIZADEH A AND LEVICK P. 2012. Capsular contracture - what are the risk factors? A 14 year series of 1400 consecutive augmentations. J Plast Reconstr Aesthet Surg 65: 213-218.

DE LA PEÑA-SALCEDO JA, SOTO-MIRANDA MA AND LOPEZ-SALGUERO JF. 2012. Back to the future: a 15year experience with polyurethane foam-covered breast implants using the partial-subfascial technique. Aesth Plast Surg 36: 331-338.

DELAVARY BM, VAN DER VEER WM, VAN EGMOND M, NIESSEN FB AND BEELEN RH. 2011. Macrophages in skin injury and repair. Immunobiology 216: 753-762.

DEVOR DE, WAALKES MP, GOERING P AND REHM S. 1993. Development of an Animal Model for Testing Human Breast Implantation Materials. Toxicol Pathol 21: 261-273.

DUXBURY PJ AND HARVEY JR. 2016. Systematic review of the effectiveness of polyurethane-coated compared with textured silicone implants in breast surgery. J Plast Reconstr Aesthet Surg 69: 452-460.

EKDHAL KN, LAMBRIS JD, ELWING H, RICKLIN D, NILSSON PH, TERAMURA Y, NICHOLLS IA AND NILSSON B. 2011. Innate immunity activation on biomaterial surfaces: A mechanistic model and coping strategies. Adv Drug Deliv Rev 63: 1042-1050.

ER TK, TSAI SM, WU SH, CHIANG W, LIN HC, LIN SF, WU SH, TSAI LY AND LIU TZ. 2007. Antioxidant status and superoxide anion radical generation in acute myeloid leukemia. Clin Biochem 40: 1015-1019.

FRAME J, KAMEL D, OLIVAN M AND CINTRA H. 2015. The in vivo Pericapsular Tissue Response to Modern 
Polyurtehane Breast Implants. Aesth Plast Surg 39: 713723.

FRANZ S, RAMMELT S, SCHARNWEBER D AND SIMON JC. 2011. Immune response to implants - A review of the implications for the design of immunomodulatory biomaterials. Biomaterials 32: 6692-6709.

GRETZER C, GISSELFÄLT K, LILJENSTEN E, RYDÉN L AND THOMSEN P. 2003. Adhesion, apoptosis and cytokine release of human mononuclear cells cultured on degradable poly(urethane urea), polystyrene and titanium in vitro. Biomaterials 24: 2843-2852.

GUELCHER SA. 2008. Biodegradable polyurethanes: synthesis and applications in regenerative medicine. Tissue Eng Part B Rev 14: 3-17.

HEADLAND SE AND NORLING LV. 2015. The resolution of inflammation: Principles and challenges. Semmin Immumol 27: 149-160.

HÖHN A, JUNG T AND GRUNE T. 2014. Pathophysiological importance of aggregated damaged proteins. Free Rad Bio Med 71: 70-89.

JONES KS. 2008. Effects of biomaterial-induced inflammation on fibrosis and rejection. Semin Immunol 20: 130-136.

LABOW RS, MEEK E AND SANTERRE JP. 1998. Differential synthesis of cholesterol esterase by monocytederived macrophages cultured on poly(ether or ester)based poly(urethane)s. J Biomed Mater Res 39: 469-477.

LABOW RS, MEEK E AND SANTERRE JP. 2001. Model systems to assess the destructive potential of human neutrophils and monocyte-derived macrophages during the acute and chronic phases of inflammation. J Biomed Mater Res 54: 189-197.

MENDES PRS, BINS-ELY J, LIMA EAS, DE VASCONCELLOS ZAC, D'ACAMPORA AJ AND D' EÇA NEVES R. 2008. Histological study on acute inflammatory reaction to polyurethane-coated silicone implants in rats. Acta Cir Bras 23: 93-101.

MOSSAAD BM AND FRAME JD. 2012. Correction of breast contour deformities using polyurethane breast implant capsule in revisional breast surgery. J Plast Reconstr Aesth Surg 65: 1425-1429.

ORTEGA-GÓMEZ A, PERRETTI M AND SOEHNLEIN O. 2013. Resolution of inflammation: an integrated view. EMBO Mol Med 5: 661-674.

REES MD, KENNETT EC, WHITELOCK JM AND DAVIES MJ. 2008. Oxidative damage to extracellular matrix and its role in human pathologies. Free Radic Biol Med 44: 1973-2001.

SANTERRE JP, WOODHOUSEB K, LAROCHED G AND LABOW RS. 2005. Understanding the biodegradation of polyurethanes: From classical implants to tissue engineering materials. Biomaterials 26: 7457-7470.

SCARPA CS, BORSO GF, VINDIGNI V AND BASSETTO F. 2015. Polyurethane foam-covered breast implants: a justified choice? Eur Rev Med Pharmacol Sci 19: 16001616.

SCHÄFER M AND WERNE S. 2008. Oxidative stress in normal and impaired wound repair. Pharmacol Res 58: 165-171.

SERHAN CN, BRAIN SD, BUCKLEY CD, GILROY DW, HASLETT C, O'NEILL LA, PERRETTI M, ROSSI AG AND WALLACE JL. 2011. Resolution of inflammation: state of the art, definitions and terms. FASEB J 21: 325332.

SHUTTE RJ, XIE L, KLITZMAN B AND REICHERT WM. 2009. In vivo cytokine-associated responses to biomaterials. Biomaterials 30: 160-168.

STRECKER-MCGRAW MK, JONES TR AND BAER DG. 2007. Soft Tissue Wounds and Principles of Healing. Emerg Med Clin N Am 25: 1-22.

SUTHERLAND K, MAHONEY II JR, COURY AJ AND EATON JW. 1993. Degradation of biomaterials by phagocyte-derived oxidants. J Clin Invest 92: 2360-2367.

TAHARA S, MATSUO M AND KANEKO T. 2001. Agerelated changes in oxidative damage to lipids and DNA in rat skin. Mech Ageing Dev 122: 415-426.

THEVENOT PT, BAKER DW, WENG H, SUN MW AND TANG L. 2011. The pivotal role of fibrocytes and mast cells in mediating fibrotic reactions to biomaterials. Biomaterials 32: 8394-8403.

VIEIRA VJ, D'ACAMPORA AJ, MARCOS AWB, DI GIUNTA G, DE VASCONCELLOS ZA, BINS-ELY J, D'EÇA NEVES R AND FIGUEIREDO CP. 2010. Vascular endothelial growth factor overexpression positively modulates the characteristics of periprosthetic tissue of polyurethane-coated silicone breast implant in rats. Plast Reconstr Surg 126: 1899-1910.

WAGENFÜHR-JÚNIOR J, RIBAS-FILHO JM, NASCIMENTO MM, RIBAS FM, WANKA MV AND GODOI AL. 2012. Histopathological reaction over prosthesis surface covered with silicone and polyurethane foam implanted in rats. Acta Cir Bras 27: 866-873.

ZHAIZ, GOMEZ-MEJIBASE, GIMENEZ MS, DETERDING LJ, TOMER KB, MASON RP, ASHBY MT AND RAMIREZ DC. 2012. Free radical-operated proteotoxic stress in macrophages primed with lipopolysaccharide. Free Rad Bio Med 53: 172-181. 